\section{Exposure to 'smokescreen' marketing during the 2018 Formula 1 Championship}

\section{INTRODUCTION}

Tobacco advertising and sponsorship in Formula 1 (F1) racing, which was banned in Europe by the 2005 EU Tobacco Advertising Directive ${ }^{1}$ and internationally by the Federation Internationale de l'Automobile since $2006,{ }^{2}$ continues to this day through the Philip Morris sponsorship of Ferrari, ${ }^{3}$ thought to be worth $\$ 160$ million ( $£ 124$ million) annually. ${ }^{4}$

Although Marlboro advertising and related barcode alibis disappeared from Ferrari cars after 2010, ${ }^{5}$ during the 2018 championship, Philip Morris introduced a new marketing campaign, Mission Winnow, with text and logo branding on Ferrari cars and uniforms. Philip Morris states that Mission Winnow promotes their drive towards alternatives to traditional cigarettes and does not advertise tobacco products. ${ }^{6}$ However, the branding is strongly reminiscent of the Marlboro Chevron logo, ${ }^{4}$ and the trademark details for Mission Winnow include tobacco products. ${ }^{7}$ We argue that Mission Winnow is 'smokescreen' marketing, covertly advertising tobacco products, ${ }^{8}$ with much in common with Philip Morris's earlier Marlboro barcode livery. ${ }^{5}$

We have quantified the tobacco content in the 2018 F1 Championship to assess compliance with regulatory restraints and to estimate audience exposure to this smokescreen marketing.

\section{METHODS}

We measured all tobacco contents shown on screen during the UK F1 race broadcasts (including both prerace and postrace footages) shown on Channel 4 for all 21 races during the 2018 championship, using 1 min interval coding. ${ }^{9}$ The coding method includes recording the presence or absence of audio-visual tobacco content during every 1 minute interval of footage in four categories: 'actual use' (actual smoking shown on screen), 'implied use' (any inferred use without actual use being shown on screen), 'paraphernalia' (the presence onscreen of tobacco or other related materials) and 'brand appearance' (the presence of clear and unambiguous branding).

\section{RESULTS}

A total of 3396 intervals were coded, and tobacco content occurred in 281
$(8 \%)$ of them. Tobacco content consisted of seven intervals, where a no-smoking sign can be seen, one verbal mention by a presenter of 'Philip Morris' and branding in 281 intervals. Only two brands were identified: Marlboro, which was seen on screen 67 times in 21 intervals, mostly during prerace and postrace broadcast footages (typically historical footage showing branding on cars or track signage, or in photographs of vehicles, drivers or team members) and once on an audience member's clothing in a montage shown before an advertisement break; and Mission Winnow, which appeared in five races broadcast after the launch of the brand at the Japanese Grand Prix in October 2018, occurring 668 times in 261 intervals on Ferrari vehicles, clothing and equipment.

We estimated UK audience exposure using viewing data, ${ }^{10}$ UK midyear population estimates for $2017^{11}$ and our content analysis to estimate gross and per capita impressions by age group, using previously reported methods. ${ }^{9}$ Historical footage of Marlboro advertising in races delivered an estimated 37 million (95\% CI 34.14 to 41.51 ) gross impressions to the UK population, including 1.2 million (95\% CI 0.92 to 1.48 ) to children, while Mission Winnow branding on Ferrari cars in the final five races of the season resulted in 438 million (95\% CI 395 to 481) gross impressions being delivered to the UK population, including 14 million (95\% CI 10.81 to 17.49 ) to children.

\section{DISCUSSION}

This study demonstrates that, despite the ban on tobacco advertising in $\mathrm{F} 1,{ }^{12}$ tobacco content and branding were shown in UK broadcast footage of the 2018 F1 Championship and delivered millions of impressions of Philip Morris tobacco logos or trademarks (Marlboro and Mission Winnow) to both children and adults in the UK.

In addition to the individual $\mathrm{F} 1$ race events, Channel 4 broadcast a range of qualifying race and pre-event and postevent programmes. Since we limited the present analysis to the broadcast programmes containing the actual race as specified by Channel 4 and did not code F1 races and related content broadcast in the UK through Sky Sports F1, our analysis probably underestimated the total numbers of Philip Morris tobacco impressions delivered through F1-related programming in the UK. Furthermore, since the F1 Championships are international events with global audiences, the UK exposure figures probably represent a very small proportion of the true total global exposure.

As of February 2019, however, exposure to tobacco marketing in F1 is no longer limited to Philip Morris products, since the McLaren team has now started to carry new smokescreen marketing from British American Tobacco, which has launched its 'A Better Tomorrow' brand, also purporting to promote reduced risk products and bearing similarity to 'Lucky Strike' branding. ${ }^{4}$ It appears that, despite prohibition, tobacco advertising in Formula 1 racing broadcast is alive and well.

\section{Alexander B Barker 두, Magdalena Opazo Breton, ${ }^{1}$ Rachael L Murray $\odot{ }^{1}$ 'Bruce Grant-Braham, ${ }^{2}$ John Britton ${ }^{1}$}

${ }^{1}$ Division of Epidemiology and Public Health, UK Centre for Tobacco and Alcohol Studies, Clinical Sciences Building, City Hospital, University of Nottingham, Nottingham, UK

Bournemouth University, Talbot Campus, Poole, UK

Correspondence to Dr Alexander B Barker, Division of Epidemiology and Public Health, UK Centre for Tobacco and Alcohol Studies, Clinical Sciences Building, City Hospital, University of Nottingham, Nottingham NG7 2RD, UK; alexander.barker@nottingham.ac.uk

Contributors ABB, RLM and JB designed the study. $A B B$ led coding of data and the data analysis and contributed to the drafting of the initial manuscript. MOB supported the data analysis. BGB contributed with interpreting the findings of the study and contributing to the manuscript. RLM and JB contributed to the manuscript.

Funding This work was supported by the Medical Research Council (grant number MR/K023195/1) and the UK Centre for Tobacco and Alcohol Studies, with core funding from the British Heart Foundation, Cancer Research UK, Economic and Social Research Council and the Department of Health under the auspices of the UK Clinical Research Collaboration. The funders had no role in the study design, data collection and analysis, decision to publish or preparation of the manuscript.

Competing interests None declared.

Patient consent for publication Not required.

Provenance and peer review Not commissioned; externally peer reviewed.

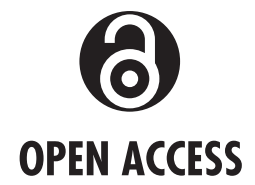

Open access This is an open access article distributed in accordance with the Creative Commons Attribution 4.0 Unported (CC BY 4.0) license, which permits others to copy, redistribute, remix, transform and build upon this work for any purpose, provided the original work is properly cited, a link to the licence is given, and indication of whether changes were made. See: https:// creativecommons.org/licenses/by/4.0/.

C Author(s) (or their employer(s)) 2019. Re-use permitted under CC BY. Published by BMJ.

\section{Check for updates}

To cite Barker AB, Opazo Breton M, Murray RL, et al. Tob Control 2019;28:e154-e155. 
Received 22 February 2019

Revised 16 April 2019

Accepted 26 April 2019

Published Online First 30 May 2019

Tob Control 2019:28:e154-e155.

doi:10.1136/tobaccocontrol-2019-055025

ORCID iDs

Alexander B Barker http://orcid.org/0000-0003-4568-

5114

Rachael L Murray http://orcid.org/0000-0001-54772557

\section{REFERENCES}

1 European Commision. Double-blow to tobacco: Byrne welcomes political agreement on cigarettes advertising ban and smoking prevention measures, 2002.

Available: http://europa.eu/rapid/press-release_IP-021788_en.htm?locale=en
2 Federation Internationale De L'Automobile. Tobacco sponsorship of motorsport - Achieving an effective ban by world-wide agreement in 2006: A statement by the FIA, 2002. Available: http://www.autoracing1.com/ PDFs/2002/0418FIATobacco.pdf

3 Planet F1. Philip Morris extend Ferrari sponsorship deal, 2018. Available: https://www.planetf1.com/news/ marlboro-to-feature-on-ferraris-2018-car/

4 Chapman M. Is tobacco giant pulling a fast one? F1 sponsor faces probe as government adviser claims clever design breaches advert ban. The Daily Mail, 2019.

5 Grant-Braham B, Britton J. Motor racing, tobacco company sponsorship, barcodes and alibi marketing. Tob Control 2012;21:529-35.

6 Grand Prix 24/7. Di Giovanni: mission Winnow respect Australian laws, 2019. Available: https://www. grandprix247.com/2019/02/09/di-giovanni-missionwinnow-respect-australian-laws/
7 Justia Trademarks. Mission Winnow - Trademark Details, 2018. Available: https://trademarks.justia.com/ 880/62/mission-88062772.html

8 Grand Prix 24/7. Australia investigates mission Winnow Smokescreen for Marlboro, 2019. Available: https://www.grandprix247.com/2019/02/08/australiainvestigates-mission-winnow-smokescreen-formarlborol

9 Barker AB, Opazo Breton M, Cranwell J, et al. Population exposure to smoking and tobacco branding in the UK reality show 'Love Island'. Tob Control 2018:27:709-11.

10 Digital I. Digital.I: a fresh perspective on TV viewing figures, 2018. Available: http://www.digital-i.com

11 Office for National Statistics. Population estimates for the UK, England and Wales, Scotland and Northern Ireland: mid 2017, 2018. Available: https://www.ons. gov.uk/peoplepopulationandcommunity/populationan dmigration/populationestimates/bulletins/annualmi dyearpopulationestimates/mid2017 